\title{
TFE3/ASPSCR1 Fusion Gene
}

National Cancer Institute

\section{Source}

National Cancer Institute. TFE3/ASPSCR1 Fusion Gene. NCI Thesaurus. Code 199685.

A fusion gene that results from chromosomal translocation $t(X ; 17)(p 11.2 ; q 25)$ or $\operatorname{der}(X) t(X ; 17)(p 11 ; q 25)$ which fuses exon 2 or 3 of the TFE gene to the 3 ' half of the ASPSCR1 gene. This fusion is associated with both alveolar soft part sarcoma and primary renal cell carcinoma. 